\title{
The Ricardo Story
}

Sir Harry Ricardo (1885-1974) was one of the true pioneers of the internal combustion engine. Describing his own life and the technical developments he witnessed and influenced, Ricardo's story reflects the zest and passionate interest that led him to the top of his profession.

The Ricardo Story is a first-hand account of the author's many technical breakthroughs. Ricardo discusses his early, pre-World War I work on the internal combustion engine. He designed the engines for the first tanks in 1916. He was probably the first engineer to investigate the problem of knock in engines. He was responsible for many developments in the design of engines for World War I aircraft.

The Ricardo Story also covers the post-war transformation of the internal combustion engine, how his work assisted the first non-stop Atlantic flight, and the 1919 formation of his own company offering research to industry, which still prospers as Ricardo Consulting Engineers Ltd.

His legacy? The Ricardo turbulent head, the Ricardo research engine, the Ricardo Comet combustion system that heralded the diesel as an automotive power unit, and much more - all recognized as the product of this pioneer and the radical developments during the formative years of the internal combustion engine.

Told with the man's characteristic warmth and modesty, The Ricardo Story is a fascinating account of those historic days and achievements. 



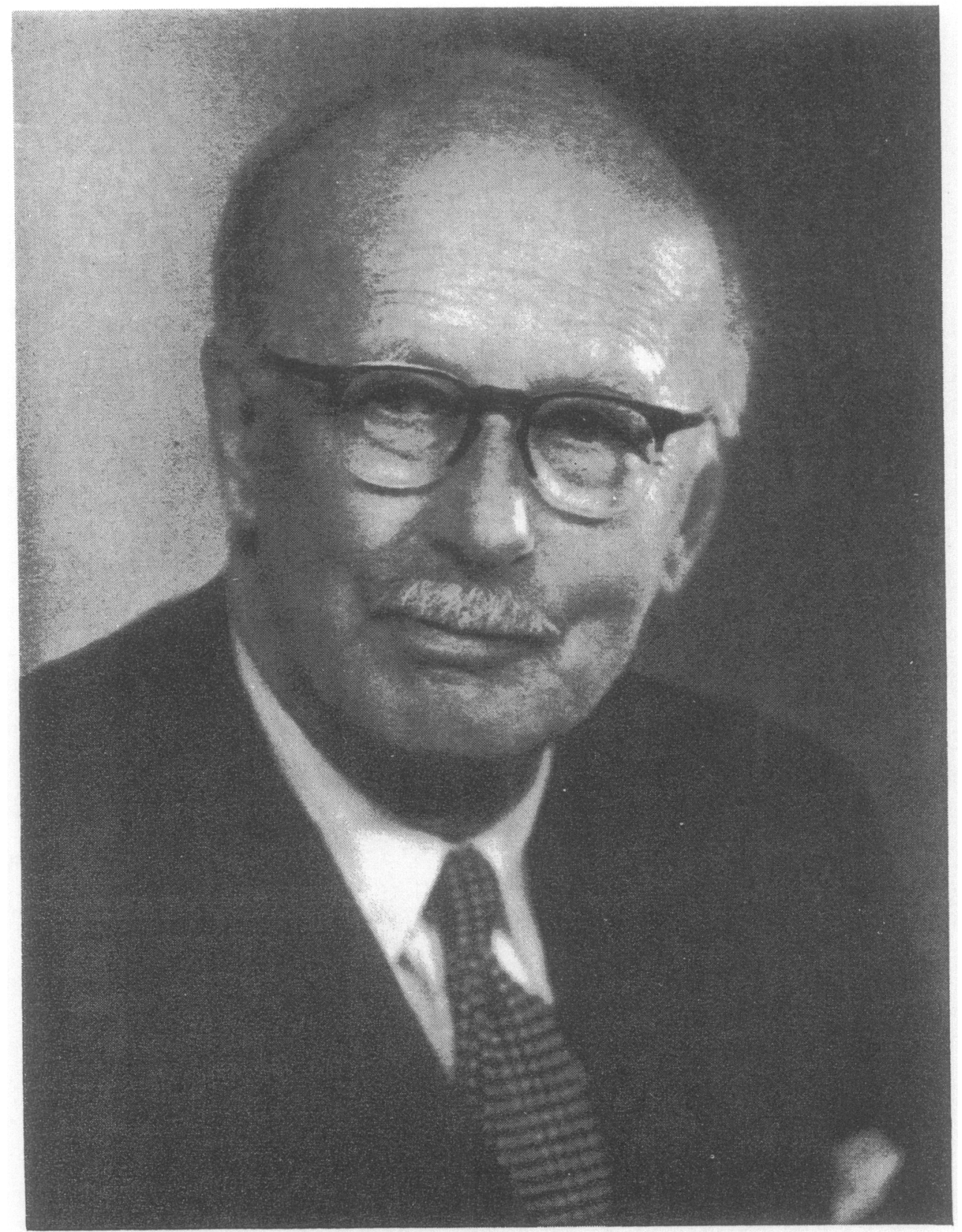

Harry R. Ricardo 



\title{
THE RICARDO STORY \\ The Autobiography of Sir Harry Ricardo, Pioneer of Engine Research
}

Second Edition

\section{SAE Historical Series}

\author{
Published by: \\ Society of Automotive Engineers, Inc. \\ 4 oo Commonwealth Drive \\ Warrendale, PA 15096-ooor
}


First published as Memories and Machines: The Pattern of My Life by Constable \& Co. Ltd. in 1968. Printed in Great Britain.

Reprinted in 1990 by Ricardo Consulting Engineers Ltd.

\section{Library of Congress Cataloging-in-Publication Data}

Ricardo, Harry R. (Harry Ralph), Sir, b. 1885.

[Memories and machines]

The Ricardo story : the autobiography of Sir Harry

Ricardo, pioneer of engine research._-2nd ed.

p. $\quad \mathrm{cm}$.-(SAE historical series)

Includes index.

ISBN 1-56og1-211-1

1. Ricardo, Harry R. (Harry Ralph), Sir, b. 1885 .

2. Mechanical engineers-Great Britain-Biography.

I. Title. II. Series.

TJ14o.R5 $\mathrm{A}_{3} 1992$

$621^{\prime} .092-\mathrm{dc} 20$

[B]

Copyright (C) 1992 Nicholas Burns

ISBN 1-56og1-211-1

All rights reserved. Printed in the United States of America.

Permission to photocopy for internal or personal use, or the internal or personal use of specific clients, is granted by SAE for libraries and other users registered with the Copyright Clearance Center (CCC), provided that the base fee of $\$ .50$ per page is paid directly to CCC, 27 Congress St., Salem, MA 01970. Special requests should be addressed to the SAE Publications Group. 1-56og1-211-1/92 \$.50. 


\section{Contents}

Preface to Second Edition page 7

Foreword 9

1 Early Life 13

Activities in London - my family and friends holidays and growing up

2 Family Background 28

3 Schooldays $\quad 3^{8}$

4 Mechanical Engineering at the Turn of the Century $\quad 5^{1}$

Steam engines - railways - gas engines - Hornsby

Ackroyd and Diesel - hot air engines - the horseless carriage

5 Some Early Endeavours

Steam engines and my first internal combustion engine

6 Cambridge

The fuel economy run - research work with Hopkinson

7 The Dolphin Venture

Design and manufacture of an engine and some motor cars

8 Start of a Career with my Grandfather's Firm

Mechanical engineering in a civil engineering context

- early work on the internal combustion engine

9 The End of the Beginning

130

State of the art in 1914 - ships - trains - diesel engines - motor cars - aircraft

10 The First World War

147

11 The First Tanks

165

Controversy at their birth - their engines 
12 Formation of my Company page 182 Working with Hopkinson again - the Air Ministry

13 A New Direction

Post-war - transformation of the I.C. engine development of the Turbulent Cylinder Head - petrol fuel investigation - the first Atlantic crossing - alcohol for engine fuel

14 Some Episodes from the New Company Bearings and lubricants - a strange accident that confirmed a theory - sleeve-valve engines - the airship controversy - engines for the R1oo-our early clients

15 Patents and Royalties

A patent action that meant life or death to my hopes

16 Some Frivolous Pursuits

Postscript by Cecil French

Appendix A - Biographical Notes

Index 


\section{Illustrations}

Harry R. Ricardo

frontispiece

Harry Ricardo, aged about six facing page 12

Harry Ricardo, in his early twenties (a) greasing rear wheel bearings, (b) enjoying his pipe aboard motor launch on upper Thames

Sir Dugald Clerk

112

Professor Bertram Hopkinson, from the

portrait by Arthur T. Nowell, painted in $1911 \quad 112$

Dr Frederick Lanchester 113

Laurence Pomeroy $\quad 113$

Sir Alexander Rendel $\quad 128$

Halsey Ricardo $\quad 128$

Harry Ricardo $\quad 128$

Beatrice Ricardo, née Hale $\quad 128$

Model Steam Engine, c. $1897 \quad 129$

Pumping Engine, c. $1902 \quad 129$

Dolphin Engine, $c .1907 \quad 160$

Triumph Ricardo Motor Cycle, c. $1922 \quad 160$

Mk. V Tanks. Battle of St. Quentin, 29th

September 1918

161

Medium Mk. 'B' Tank at Metropolitan Carriage

Wagon \& Finance Company's Works 161

Dr Ormandy $\quad 164$

Frank Bernard Halford $\quad 164$

The B.H.P. engine, from which the Armstrong-

Siddeley Puma was developed 165

225 h.p. Tank Engines being built $192^{2}$

Workshop at Walton-on-Thames, c. 1914 
Workshop at Penstone, c. 1925

192

Sir Robert Waley Cohen

193

Sir Henry Royce

193

Tizard as a member of the Experimental

Flight, Upavon, 1915

193

Mervyn O'Gorman

193

The Rolls-Royce Eagle VIII engine which powered the Vickers Vimy on its Atlantic flight in June 1919

The Bristol Jupiter engine

Harry Ricardo with Harry Horning onboard ship, 1924

The Ricardo turbulent combustion chamber $\quad 231$

Woodside - the house my father built 242

On The Pearl, c. 1928. Kate Ricardo, David Pearce, Angela Ricardo

Beatrice and Harry Ricardo, 1967

Bridge Works, Shoreham-by-Sea, Sussex, photographed in $199^{\circ}$

Development of the Ricardo Comet combustion system

Longitudinal section of the E65 engine

The RR-D diesel car speed record engine with cover removed to show sleeve-valve drive

Wellworthy-Ricardo WS 5 compressor

Transverse section of four-cylinder reciprocating steam expander 


\section{Preface to Second Edition}

We engineers often use names without a thought for their original owners. The Ricardo turbulent head, Ricardo research engine, Ricardo Comet combustion system that heralded the diesel as an automotive power unit are now better known than the man who was Harry Ricardo.

This then is The Ricardo Story, from the steam-powered bicycle of his school days to the research laboratories that still bear his name. It was told by Sir Harry Ricardo himself from the vantage point of advancing years, and looks back to the dawn of our own industry. It makes fascinating, often amusing, and always enlightening reading for engineer and student alike-values recognised by the Historical Committee of the Society of Automotive Engineers, at whose instigation this edition is published.

The original first saw light as Memories and Machines, published in England by Constable and Company in 1968. A limited edition of the original text was reprinted in 1990 to mark the $75^{\text {th }}$ Anniversary of the founding of the company (now Ricardo Consulting Engineers Ltd).

The story has now been brought up to date by Cecil French, who joined Ricardo's as Personal Assistant to the Chief Scientist in $195^{2}$ and who retired as Managing Director at Shoreham in 1990.

This is a book about people as much as it is about machines. Harry Ricardo never lived in an ivory tower. His story abounds with names of fellow workers of those pioneering years. They are the names like Hetherington, Halford, Rowledge, less familiar now, with the passage of time and the transposition to the Atlantic's other shore. To help the reader place some of these dramatis personae in their historical context I have added brief biographical notes as an appendix to Sir Harry's own colorful text, which otherwise remains completely intact. It is The Ricardo Story in his own words.

It is a story of research and achievement going back to the 
infancy of the internal combustion engine, told with charm and modesty. It is a story of disappointments, told without bitterness. It has those priceless ingredients of warmth and humour, and a charity that always gives credit to the other man, when credit is due.

Apart from the contribution by Cecil French, and the biographical notes, there are some interesting photographs and drawings that have come to light since the first edition, and which illustrate various items and personalities "pictured within." The photographs come from a number of sources, but particular thanks are due to the Institution of Mechanical Engineers and the Royal Aeronautical Society, London; RollsRoyce plc; Cambridge University; RAE Farnborough; British Aerospace; and to Drs Kate Bertram and Camilla Bosanquet, daughters of the late Sir Harry Ricardo. 


\section{Foreword}

When Harry Ricardo was first asked to write a book on the internal combustion engine more than fifty years ago, he relates that the invitation came as a surprise to him, for although almost since birth he had immersed himself in engines of all kinds, he was young and little known. He took up the invitation and a faintly derisive family complained that instead of retiring like a proper author to a study, he would write amid the hubbub of family life, but the book that resulted became a much loved classic and successive editions were to remain in print until the present day. One of the original instructions was that the book was to be written in readable English and it is interesting that T.R. Henn, writing in 196o in his book Science in Writing quoted a passage from it in support of his inclusion of the author as a master of clear exposition and style among such others as Newton, Gilbert White and Darwin.

It was not until 1930 that I was old enough to become aware of the author, by which time he was, I suppose, a distinguished though not yet a famous man. Of that I was unaware, but I knew that he was an ideal uncle. He had always a genius for children, an endless supply of stories, tall and very tall, and his incessant passion for making things meant that some project was always on hand whether it was the question of a model car or boat to amuse the very young, or the construction of a floating greenhouse to test a theory of market gardening. The Ricardo household was characterised by a tremendous capacity for enjoyment, and my cousins grew up amidst a range of exciting activities punctuated at intervals by extensive travel to distant parts.

This book recounts the episodes that the author considers most significant both as regards his own full life and the technical developments which he has seen and influenced. It is of interest that the year of his birth (1885) was also the birth of the first real motor cars, for in that year both Daimler and Benz in Germany first made road vehicles fitted with internal combustion engines. 
The episodes are recounted very modestly, and in describing his career at Cambridge the author attributes a great deal to the then Professor of Mechanical Sciences Bertram Hopkinson, for his teaching and, above all, for his encouragement and invitation to assist in his research programme. Hopkinson's ideas were well ahead of his time, but he made an apt choice of assistant in the undergraduate who, before the age of twenty, seemed to have absorbed most of the current knowledge of the internal combustion engine, and who was at that time designing a two-stroke engine to embody an obscure theory put forward by Dugald Clerk. The engine, known as the 'Dolphin,' is covered by a patent specification dated 1906 (in which the author is described as a student) and proved so successful that it was made under license by a number of firms until the outbreak of war extinguished the market for it.

Before Cambridge came school, and the account of schooldays given here, while resembling those of others writing from a similar background, is particularly interesting in the picture it paints of the prospects for anyone wanting to learn anything of science or technology. In one of the best schools in a country grown rich largely because of its lead in technical development, the official timetable scarcely troubled about such things. Fortunately it was a tolerant establishment that allowed the author to develop his favourite pastime of finding out for himself, but clearly a good deal of determination was needed to do so.

In the First World War the author implies that it was only by chance that he was able to make any worthwhile contribution after two miserable years of inactivity. In fact it was a case of opportunity offered to a well-prepared mind. The authorities were slow to recognise the significance of the internal combustion engine in warfare, but when the need for engines suddenly became insistent both for new developments such as the Tanks, and for the disregarded aeroplane, it was essential to mobilise all the talent that this country afforded. Among the small band of people who knew what they were doing, Ricardo's knowledge and experience commanded respect, and it was for this reason that the chance was given to him. The Tanks were to play a large part in bringing the war to an end, but at their birth there was 
no engine of adequate power available for them, and their whole future depended upon the rapid development of an engine to meet their peculiar requirements. This challenge the author was able to meet, but it was by good judgment rather than by luck.

The start and early days of the company that is now known all around the world as 'Ricardo's' is recounted modestly enough toward the end of the book. It must have seemed an unlikely venture to succeed and must rank as one of the very few enterprises that have been able to make research and development pay without benefit of grants or subsidies. There were, of course, hard times in the early days, but many who joined the firm then were to remain for the whole of their working lives; the founder was able to provide not only the necessary technical leadership but a certain buoyancy of spirit that is so apparent in the pages of this book. He made it fun. By the time of the Second World War recognition was widespread, and honours, medals, doctorates and acclaim were to come freely from this country and abroad.

A great deal of work has been carried out in the laboratories at Shoreham-by-Sea in the fifty years' existence of the firm, but probably no single project has been of greater significance than the initial programme to investigate knock in the petrol engine, supported by the Shell Petroleum Company in 1919. In what now seems a remarkably short time the programme had more than fulfilled its objects, and provided the means for great advances in fuel quality to be made. That the programme was so quickly fulfilled was again due to the fact that the author had already formed a clear picture of the probable mechanisms of knock from his own early work. By the end of the First World War others had tumbled to the significance of knock and had also begun to research into it, but when in 1913 Ricardo persuaded a consulting chemist to supply him with samples of different fuels in order to assess them on his own test engine in the garden at Walton-on-Thames he was probably the first person ever to attack the problem methodically.

The success of the programme gave the new company a flying start, and the importance and integrity of the work carried out 
in the first ten years were recognised by a Fellowship of the Royal Society in 1929, a rare distinction for an engineer.

Because the author felt that radical developments in the early days of the internal combustion engine were of more interest than the steady progress of recent times and because of his awareness of the influence of his own early activities on his career, the emphasis of the book is on the early days and it ends at a time before the Second World War. This of course was not really the end of the story because with the author as chairman until 1965 and subsequently president, his company continued to prosper and expand on the lines originally designed. Further recognition was to come with a knighthood in 1948 and since that time the company has become the leading independent organisation for internal combustion engine work in the world. It serves as consultants to engine manufacturers in almost every industrialised country and its patents are used worldwide.

In writing this book my uncle had to develop a new technique. As far as I know he had never previously dictated a sentence, and all his earlier writings, whether letters, papers, speeches or books were written out in longhand, but by this time failing sight had made it necessary to resort to dictation. The transcriptions could only be read back after an interval, and thinking that clumsiness and repetition might occur with such a method, he asked me to help him with polishing the text. In fact, I have had little to do, surely a tribute to that ability for complete concentration which was apparent when writing his first book, and which like his astonishing memory has always seemed a most striking characteristic to anyone who has known him well.

Hazel Grove 1968 


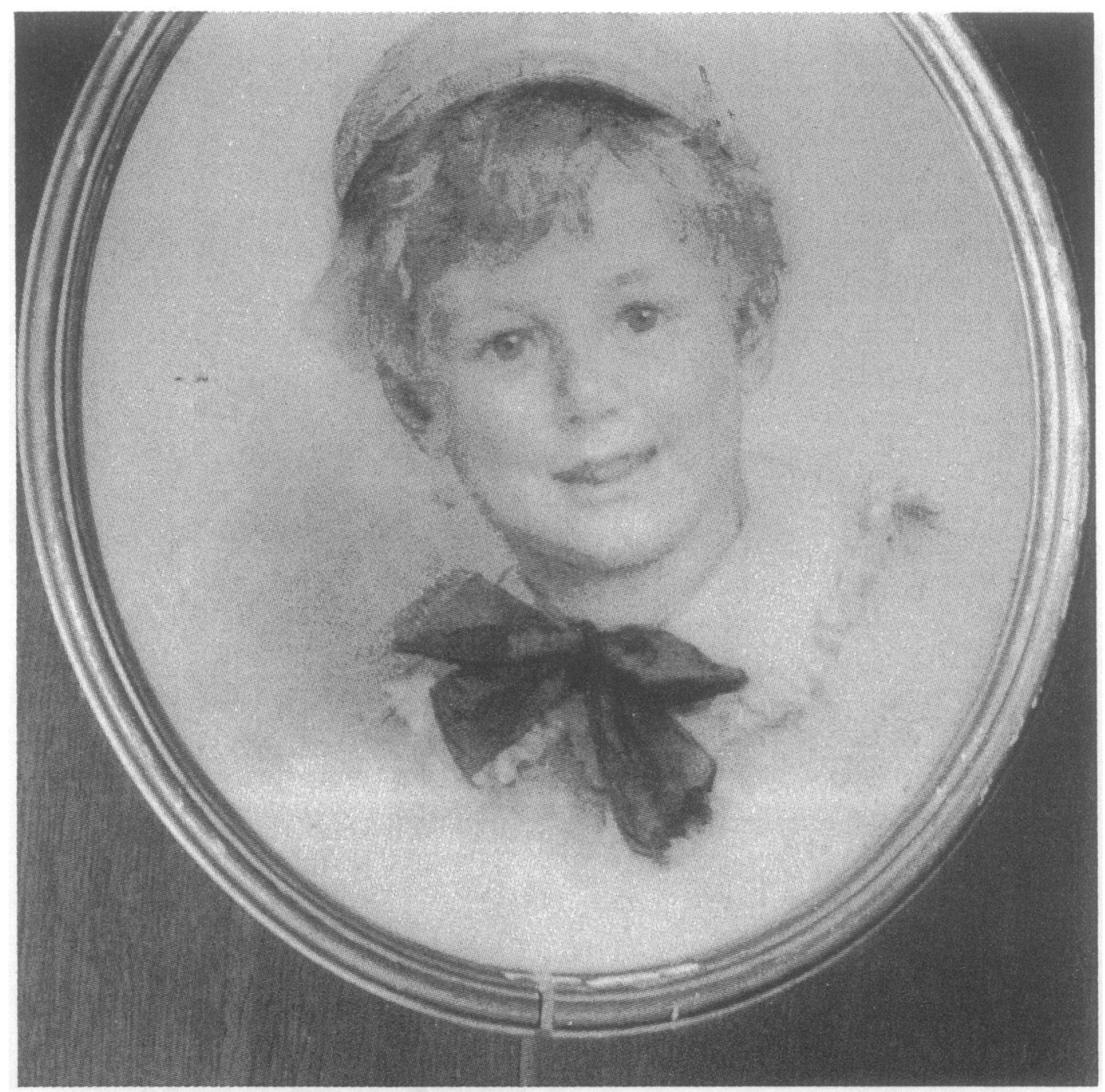

Harry Ricardo, aged about six 


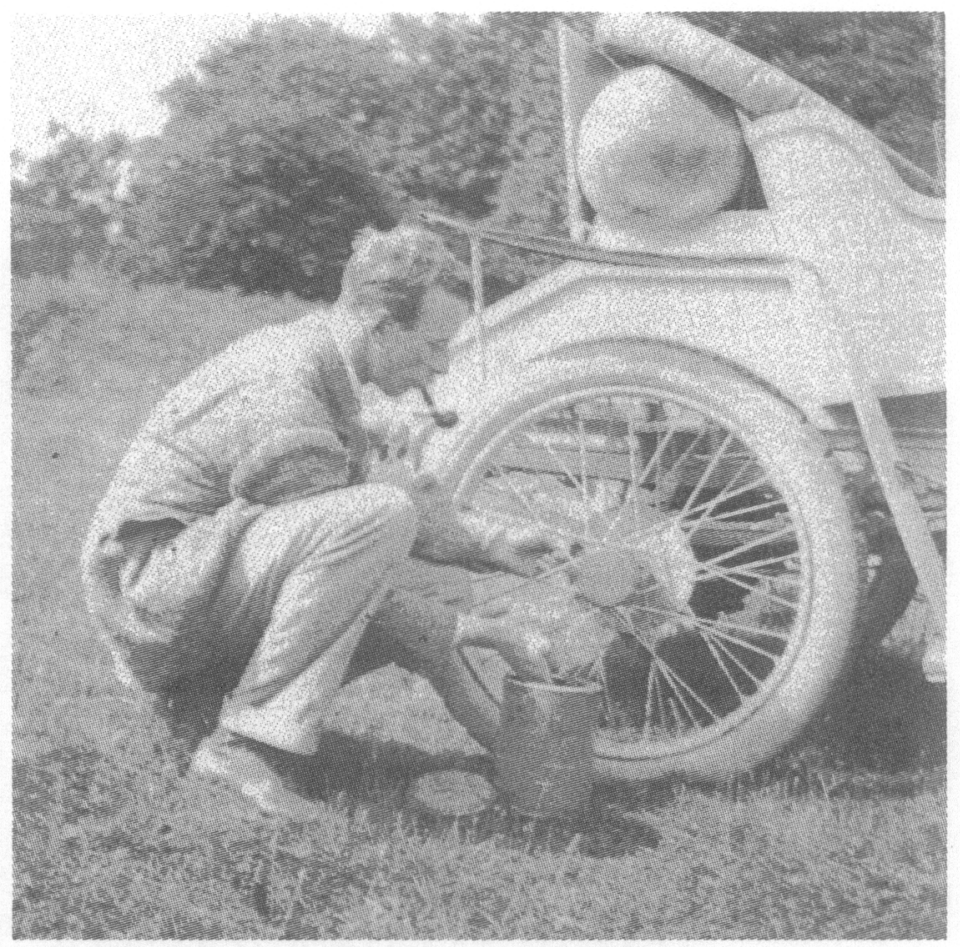

(a)

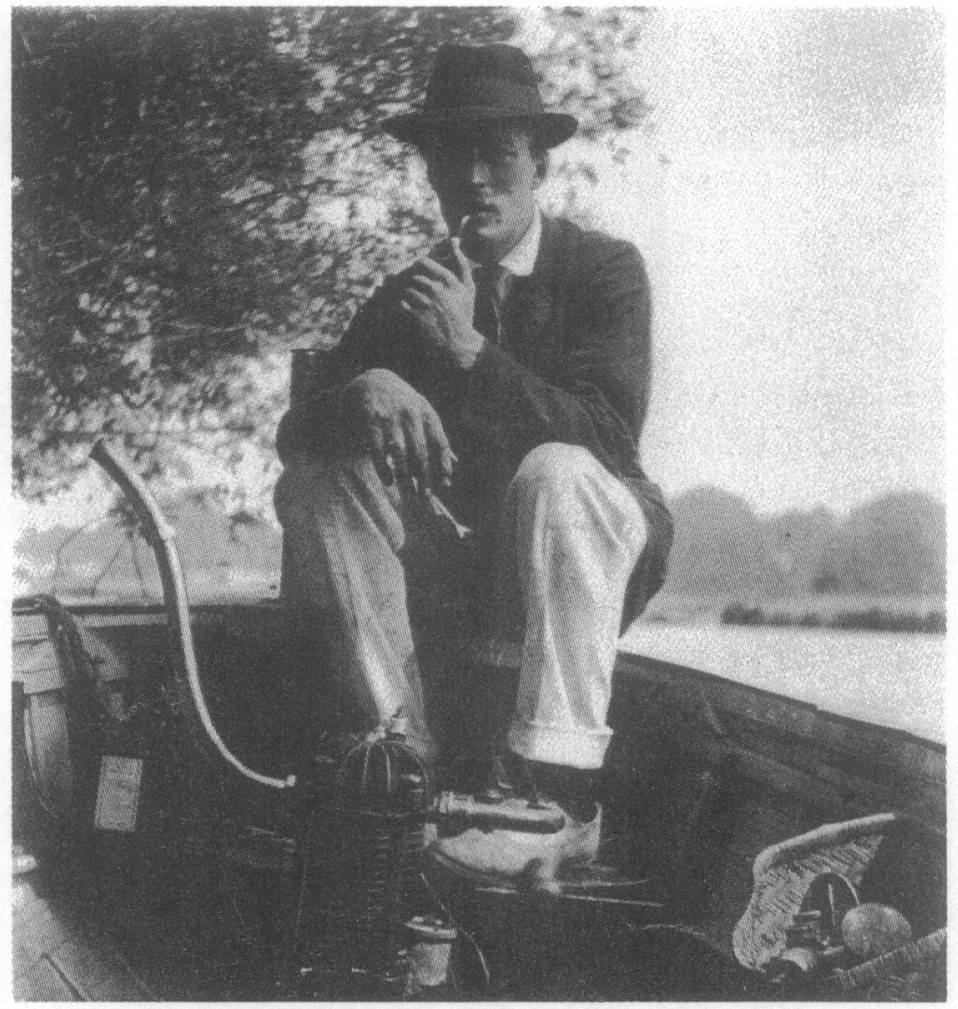

(b)

Harry Ricardo, in his early twenties (a) greasing rear wheel bearings, (b) enjoying his pipe aboard motor launch on upper Thames 